\title{
THE PREVENTION OF FUTURE CONFLICT IN IRAQ: POLICY RESEARCH AT DFAIT - A CASE STUDY
}

\section{David M. Malone and Ben Rowswel**}

\section{INTRODUCTION}

$\mathrm{D}$ ebates over global terrorism, the spread of weapons of mass destruction, the legitimacy of the use of force, and the role of the United States all demonstrate that we have entered a period of rapid change in the international security environment. The implications for Canada are profound as we face new and uncertain challenges, not least in Afghanistan.

Policy research takes on greater urgency in times like these. Focused deliberation can sharpen analysis of the challenges of the day, identify options, depoliticise debates, and generate evidence for informed policy decisions. That is why the Canadian federal government, through the Department of National Defence, the Canadian International Development Agency (CIDA), and the Foreign Affairs and International Trade Canada (DFAIT) contribute financially and in other ways to policy development initiatives launched within Canadian and international universities, research institutions and NGOs, frequently in partnership with other governments.

While Ottawa is not one of the world's major cities, nor one of Canada's dominant intellectual centres, its role as the capital of a G-8 country, its two universities (one, the University of Ottawa, with a strong tradition in international law, the other, Carleton University, with an outstanding graduate school of international affairs), the presence of a robust NGO community and several research institutions active on international relations, such as the International Development Research Centre and the North-South Institute, provide a steady supply of interesting visitors able and willing to stimulate new ideas.

While policy research plays a useful background role in deepening the sophistication of Canada's foreign policy, there are instances in which policy research forms a key part of Canada's response to specific crises. The two of us were involved in one such initiative.

As Iraq's transition from the 2003 intervention by the United States and United Kingdom to the launch of a new constitutional order came to an end in early 2006, all signs pointed to prolonged fighting that could very easily engulf a new generation of Iraqis, much as the generation from 1980 to 2005 had known nothing but warfare. With limited influence and no good options to manage the escalating conflict in the short term, DFAIT launched a policy research initiative to cast thoughts ahead to shape thinking about where long-term solutions might lie amid the gloom of the current situation.

This article examines the backdrop to the initiative, describes how it developed, and details some of the conclusions of the exercise. It concludes that in this particular case, policy research enabled experts and practitioners to set their sights farther ahead, generating conclusions that Canada may use to influence the agendas of key international actors. When there are no good options available in the short term, one alternative to despair or apathy lies in thinking through the solutions required over a longer time horizon. Policy research provides a means to shape international thinking around long-term solutions for problems that seem insoluble in the present.

\footnotetext{
* David M. Malone is Canada's High Commissioner in India and serves concurrently as non-resident Ambassador to Bhutan and Nepal. Ben Rowswell manages the Democracy Unit within Foreign Affairs and International Trade Canada. The views of the authors do not reflect those of the Government of Canada.
} 


\section{OPPORTUNITY FOR A CANADIAN INITIATIVE?}

For DFAIT to have undertaken a policy initiative on Iraq, however low-key, is counter-intuitive. Canada severed most diplomatic ties with Iraq in 1991 when it participated in Operation Desert Storm to eject Iraqi forces from Kuwait. Iraq thereafter was not seen as much of a priority and Canada's government strained in 2002 and 2003 to avoid involvement in efforts aiming to effect regime change in Baghdad. While opinions in Canada varied over the government's messaging at that time, and while efforts were subsequently directed at muting official criticism of US policy in Iraq, Parliament showed no appetite to reverse the government's hands off approach to Iraq.

While declining to participate in the military overthrow of the Saddam Hussein regime, Canada did offer $\$ 300$ million in funding for economic reconstruction and related goals such as police training. This was the largest contribution of any non-Coalition country. Japan, a Coalition member, chaired early consultations among international donors to Iraq, but wished to step down in 2005. A strong interest then developed in seeking a Canadian candidate for this role. Michael Bell, a former senior Canadian ambassador in the Middle East, agreed to serve as Chair of the International Reconstruction Fund Facility for Iraq. He came to play an important role in the initiative we describe here.

The challenges Iraq came to face in the wake of the Coalition's removal of Saddam Hussein centred in large part in the collapse of the state and the resulting pressure this placed on national cohesion. On the latter topic, Canada's experience with knitting together multiple communities and managing secessionist impulses through constitutional and other forms of state-building innovation was potentially relevant to Iraq. Indeed, the International Forum of Federations, an international policy development institution founded by Canada some years ago, has been active in providing advice to the Iraqi National Assembly committee responsible for drafting Iraq's new constitution.

Canada has yet to reopen its embassy in Iraq, but it did re-establish a diplomatic presence for the first time in 12 years when it sent one of us, Ben Rowswell, to Baghdad in August 2003. After a stint in Erbil while on leave with the National Democratic Institute (NDI) Rowswell headed our modest presence there until mid-2005. He returned to Ottawa with a few insights into the roots of Iraq's long-term instability and a number of ideas on how to replace the deep divisions in the international community's treatment of Iraq with a new consensus on how to address the ongoing conflict. Meanwhile, David Malone, before returning to government from a stint at the International Peace Academy in New York, had initiated a monograph on international politics and Iraq since 1980 as refracted through the UN Security Council. (Malone 2006)

Happily, the DFAIT assignment process brought them together in the Department's Global Issues Branch, of which Malone was the Assistant Deputy Minister, in September 2005. While holding no direct brief for Iraq (ably discharged in DFAIT's Middle East Bureau), the Global Issues Branch was responsible for a variety of cross-cutting issues highly relevant to Iraq, such as aid policy and allocations (in partnership with CIDA), human rights, promotion of democracy, and human security policy.

\section{THE SHAPING OF A POLICY INITIATIVE}

As the situation in Iraq deteriorated throughout 2004 and 2005, US and other international interventions came under increasing criticism for the very short-term focus that characterized them. Iraq seemed to lurch from one political milestone to the other, with all hopes placed on the next election or referendum to bring stability where previous milestones had failed. 
In late 2005, DFAIT set out to initiate some of the long-term thinking that seemed to have been so notably lacking until then. It launched a policy research project to step back from the frenetic pace of developments on the ground in Baghdad, and to consider how Iraq might be stabilized over the longer term. The purpose of the initiative was to generate new thinking on the building blocks of a successful peace-building strategy, with a view to influencing audiences in key international fora like the United Nations Secretariat.

Rowswell had returned from Iraq convinced that the roots of the current violence stretched back well before the 2003 invasion, to a state too weak to ensure law and order except through brute force. The weakness of the Iraqi state had led to perennial domestic conflict and over time the instability had spread to the region to embroil Iraq's neighbours and the international community. Left unaddressed, the common threat that instability posed to Iraqis and foreigners alike through war, genocide, and regional destabilization over the past generation promised to wreak further damage for the generation to come. Precisely because the consequences going forward are so dire, however, this shared threat should generate a shared interest in stabilizing Iraq.

Malone had become interested in how successive Iraqi crises had undermined international peace and security over the past generation. Looking forward, he was concerned that an implosion of the country might spell wider geo-strategic difficulties for Iraq's neighbours and the great powers beyond. The country's principal communities were experiencing difficulty in coming to terms with each other, and the political agenda set in place by the Coalition (involving consultative processes centred on a new constitution, and then elections for Parliament) while executed freely, fairly and on time, resolved little.

These two levels of concern meshed well with those of Markus Bouillon, a young Oxford Ph.D. sought out as an external partner. Bouillon was working with Oslo Peace Process architect, Terje Roed Larsen, at the International Peace Academy (IPA) in New York as director of an impressive Middle East program that Roed-Larsen has spurred on since taking over the IPA. If Rowswell was familiar with conditions on the ground in Iraq and Malone had particular insights into the dynamics of the international debate over Iraq, Bouillon brought a sophisticated understanding of the broader Middle Eastern context to the team. ${ }^{1}$

Having explored various possible areas of focus for a consultation on Iraq hosted by the Canadian foreign ministry and co-sponsored by IPA, these three individuals ultimately concluded that the US-led Coalition had exhausted any potential it could have in mobilizing the broad international support required to stabilize Iraq. As the United States ran out of options to manage an increasingly violent situation in Iraq, other international actors would be compelled to deal with Iraq as ongoing conflict posed a growing threat to all.

The United Nations could not be the sole focus of any renewed international attention in Iraq, but it might now play a role in bringing together key Iraqi and international actors to hammer out an agreed international strategy. President Bush had prevailed on the United Nations to help with the formation of Iraq's interim government in early 2004, and while not all of the UN's advice was heeded, the personal authority of its envoy, Lakhdar Brahimi, had helped secure a relatively positive outcome. Fortunately, Brahimi, who had worked closely and well with Canadians in Haiti, South Africa, Afghanistan and New York, agreed to come to Ottawa.

\footnotetext{
1 Terje Roed-Larsen, at the time of writing, served as Kofi Annan's Special Envoy for the implementation of Security Council Resolution 1559 on Lebanon, and remained deeply committed to securing peace between Israel and its neighbours.
} 
Brahimi's presence encouraged a number of key Iraqi figures and world-renowned Iraq experts to participate. His already high standing had most recently been enhanced by his role in regenerating Afghan politics around Hamid Karzai through the Bonn conference of December, 2001, and subsequently by his service as UN Special Representative on the ground in Kabul, 2002-2003. ${ }^{2}$

In order to cast the consultation in the most constructive light possible, its three organizers agreed to centre it on the notion of the prevention of future conflict in Iraq at a time when civil war threatened to engulf the country and the region in another generation of violence.

\section{ORGANIZING A CHALLENGING CONSULTATION}

In early 2006, everything about Iraq was sensitive. Relationships among Iraqis were tense, certainly as viewed through the lens of inter-communal ties. Each community was sure to be vigilant about how it was represented in any discussion of Iraq's future. Further, Coalition countries, if not briefed on the consultation's aims, might perceive the initiative as unhelpful. How would the new Iraqi government react? And would the United Nations be at all interested?

Further, given the risks that a Canadian-hosted discussion on Iraq could be misinterpreted as signalling a shift in Canadian policy, high-level support was vital. Throughout, the Deputy Minister of Foreign Affairs, Peter Harder, was supportive as had been Prime Minister Martin's Foreign Policy Advisor. With a change in government in Ottawa, the new Foreign Minister's view was sought early on: Peter MacKay immediately endorsed the initiative. ${ }^{3}$

The three organizers soon faced an organizational dilemma: should the conference aim primarily to involve Iraqis in a dialogue with each other, or should it bring together leading international experts on Iraq knowledgeable about other conflict situations and more experienced in designing strategies to prevent internal conflict and international war. They decided to combine both approaches, by inviting international experts to speak to critical issues, and by inviting a diverse group of Iraqis to inject "ground truth" into the discussions.

Hosting the event in Canada presented a further challenge: travel from Iraq would be dangerous for Iraqi participants and several of the key players might not secure Canadian visas. ${ }^{4}$ Ultimately, a handful of Iraqi participants took the risk to travel down Baghdad's notorious airport road and fly to Ottawa for the conference. Other Iraqis flew in from less dangerous venues and many of the foremost experts on Iraq in the United States, Western Europe, Canada and other Middle Eastern countries agreed to attend.

When briefed, the governments of the United States and the United Kingdom encouraged the initiative, understanding that it ultimately aimed to be helpful to them as well as to Iraqis and other actors by focusing on Iraq's future, not on the contentious history of the Coalition's policies in Iraq. More delicate was the Iraqi government, represented in Canada by a distinguished and highly

\footnotetext{
2 Senior officials in Ottawa were more interested in discussing with Brahimi the contemporary situation in Afghanistan, where Canada had over 2000 troops engaged under the umbrella of Operation Enduring Freedom in that country's most dangerous military zone around Kandahar. His presence in Canada for the Iraq conference thus provided the bonus of extensive consultations with him over Afghanistan, somewhat under the radar screen of the media, even though Brahimi's visit was quite open, including to any interested media.

3 DFAIT has a long tradition of policy consultation involving Canadian and international experts, much of which unfolds routinely. Indeed, it is known internationally as a policy and norm entrepreneur. However, for any policy initiative on a geo-strategically sensitive issue potentially yielding either broader policy implications, or one that could yield media coverage, political-level approval is vital.

4 It is widely supposed that when a Canadian government agency invites a foreign national to participate in aspects of its work, a visa will automatically ensue. In fact, Canadian legislation and government regulations provide the Canadian immigration authorities (who control visas) with only limited leeway in interpreting or sometimes ignoring factors in the past of an applicant that raise red flags (for example, real or suspected association with terrorist movements or repressive governments, advocacy of violence, etc.). In the event, several of those invited due to their relevance in Iraqi political debate were denied visas.
} 
committed ambassador close to the Kurdish President of Iraq, Jalal Talabani. Whereas the organizers had targeted Iraqis who might speak in a personal capacity, the ambassador felt it important to mobilize voices in favour of the official views of the Kurdistan Alliance to compensate for the effects of decades of marginalizing and excluding Kurdish views from Iraqi debates. Ultimately, these views enriched the debate, even if one or two of the non-Kurdish supporters of Kurdish interests expressed themselves with less delicacy to towards those disagreeing with them than the Pearson Building is used to hearing.

In order to encourage frank exchange among participants, the organizers thought that most of the conference needed to unfold behind closed doors. However, they did not want this initiative to be shrouded in apparent secrecy, so they arranged for an opening session to which a much broader group of participants could be invited. The Iraqi ambassador made an excellent presentation on the key challenges his country faced, greatly assisting in setting a positive tone for the meeting. Parliamentarians and a wider group of officials, non-governmental experts, and Canadian academics were invited to the conference's initial discussions before the closed door sessions, sending the message that Canadians remain acutely interested in the future of Iraq even if the country has chosen to make its primary contributions to international security elsewhere. ${ }^{5}$

Preparations were therefore set for a conference in Ottawa on May 11 and 12, 2006, that would bring together seventy prominent Iraqis, Iraq experts, representatives of multilateral institutions, Canadian academics and officials to reflect on the conflict raging in Iraq. Having launched the research initiative, the time had come to frame the discussion in terms that could help recast the international debate over Iraq and lay the groundwork for a new consensus.

\section{SETTING IRAQI INSTABILITY IN CONTEXT}

Just after the invitations had been sent out and the stage set for the Ottawa conference, a massive bombing in Samarra provided a horrific demonstration that Iraq could be at war for years, if not decades. The suicide bomb that destroyed a venerated Shi'a shrine set off a round of mayhem that killed more than 300 people in five days in Baghdad alone. There were reports of incidents eerily reminiscent of the 1975 massacre of Palestinians that launched the Lebanese civil war, as militants were reported to have stopped a bus and shot dead a number of Sunni Arabs. (Worth 2006; Knickmeyer and Ibrahim 2006; and Al-Jazeera Online 2006)

Iraq's troubles, however, did not begin in 2006, or in 2003. Ever since its creation by the British in the years following World War I, Iraq has been astonishingly fertile soil for conflict. The chronic inability of the Iraqi polity to channel competition in peaceful, legitimate ways kept the Iraqi state notoriously unstable. As Hanna Batatu pointed out, "... recurring conflicts during years of English rule and in the monarchic period reflected an underlying structural discordance." (Batatu 1978: 113) Toby Dodge identified "four interlinked structural problems" in Iraqi politics which:

fuelled the state's domestic illegitimacy, its tendency to embark on military adventurism beyond its own borders, and even the Ba'thist regime's drive to acquire weapons of mass destruction: ... first, the deployment of extreme levels of organized violence by the state to dominate and shape society; second, the use of state resources - jobs, development aid, and patronage - to buy the loyalty of sections of society; third, the use of oil revenue by the state to increase its autonomy from society; and finally, the exacerbation and re-creation by the state of communal and ethnic divisions as a strategy of rule.. (Dodge 2003: 169)

\footnotetext{
5 DFAIT's practice, supported by its current and all recent Ministers, of inviting all parties in Parliament to participate in such discussions is not widely heralded, yet is appreciated in both Houses within Parliament and helps build a shared basis of knowledge on which more informed (if sometimes contentious) debate can take place. Interestingly, perhaps because of the openness with which the consultation was organized, the media displayed little interest, perhaps seeing the event as simply one more Ottawa talk-fest.
} 
The weakness of the Iraqi state exposed it to violent competition as armed factions vied for power through coups and countercoups. This cycle only stopped in 1968 with the arrival to power of the most ruthless of the lot, Saddam Hussein.

Certain individuals matter greatly in the history of nations, for good and ill. Delusions of grandeur reminiscent of those of the Shah of Iran were embedded in the personality cult Saddam Hussein encouraged from the time of his own accession to ultimate power in 1979. His pursuit of absolute control for himself and primacy for Iraq was deadly earnest and purposeful. His early and aggressive interest in a nuclear weapons program, thrust into the spotlight by the Israeli bombing on June 7, 1981, of Iraq's nuclear reactor at Osiraq, has now been fully documented.

Saddam Hussein rose to prominence in the Ba'ath party as its strongman, managing the state security apparatus and the party machinery after 1968 so as to place elements loyal to him in key positions. Extreme violence was to prove a hallmark of his rule, along with an atomization of Iraqi society through the regime's systematic efforts to undermine any institution that it did not control. Far from strengthening the Iraqi state, Hussein's dictatorship left it weaker.

In seeking to understand the root causes of Iraq's instability, our research took us to recent literature on the nature of failed and fragile states. This yielded useful insights into the nature of the state Saddam Hussein had bequeathed, and offered clues to the more comprehensive failure triggered by the 2003 invasion. ${ }^{6}$

Robert Rotberg, for example, has argued that if the purpose of a state is to provide its citizens with goods such as security, education, health services, economic opportunity, environmental surveillance, a legal framework and a judiciary to guarantee rule of law and basic infrastructure, then state fragility can be assessed by the inability to fulfill these obligations. ${ }^{7}$

Security is the key indicator according to Rotberg, with failed states typically enduring widespread violence against the existing regime, conflict between communities within the state, inability to control their territory and borders, growth of criminal violence, and a tendency by the authorities to "... prey on their own constituents". (Rotberg 2002a: 85-88) Furthermore, socioeconomic indicators can help to identify failed states, with increasingly unequal access to economic opportunity, which remains largely limited to the ruling oligarchy. The echoes of Iraq in Rotberg's description are striking.

The echo becomes stronger with a reading of Nazih Ayubi's exploration of a category of failed state common to the Arab world. This is the concept of the "fierce" state, which "... resorts to raw coercion in order to preserve itself, but [which] is not a 'strong' state because it lacks - to varying degrees of course - the 'infrastructural power' that enables states to penetrate society effectively ...". (Ayubi 1995: 3)

If the researchers gathered in Ottawa to discuss the conflict in Iraq largely agreed that the roots of the country's instability lay primarily in the fragility of the Iraqi state, they also believed that decades of external intervention in Iraq had exacerbated the situation.

External actors not only failed to end the 1980-1988 Iran-Iraq war for its first seven years, but may have contributed to prolonging it. Alarmed by the prospect of an Iranian victory, Western powers and the USSR tacitly supported Iraq, supplying it with arms and funding, thus also exacerbating the war. The parallel domestic repression and retaliation pursued by Saddam Hussein sowed the seeds of further instability, as outside actors turned a blind eye to the wide-scale persecution of Shi'a Iraqis. (Power 2006)

\footnotetext{
${ }^{6}$ Good examples, with direct reference to the Middle East, albeit espousing very different perspectives, are Migdal 1988; Owen 1992; and Ayubi 1995.

7 Rotberg 2002a: 85-96. See also Rotberg 2002b: 127-140; Rotberg 2003: Introduction.
} 
After a notable interregnum that included a UN-negotiated end to the Iran-Iraq war and the extraordinary solidarity of the Coalition that supported the United States in the prosecution of the 1991 Gulf War, international actors soon found themselves working at cross-purposes with regards to Iraq. The Security Council set up an extensive sanctions regime to disarm Iraq of its weapons of mass destruction, and eventually mandated a complex and ambitious humanitarian program to mitigate the effects of sanctions on the Iraqi population (the Oil for Food Program). These measures were complemented by unilateral and increasingly controversial military enforcement measures by states such as the United States, the United Kingdom and - early on - France. Periodic aerial bombardments of a non-compliant Iraq soon became a regular counterpoint to the UN's humanitarian initiatives, sending mixed messages to Iraqis and world public opinion, the latter increasingly opposed to a sanctions regime perceived as hurting Iraq's civilian population while doing little to inhibit the Iraqi regime. ${ }^{8}$

The cross-purposes at which key international actors operated became most apparent after 1997, when Security Council members began to disagree openly about the fundamental goals being pursued. The United States publicly oriented its Iraq policies toward regime change from 1997 onwards. The United Kingdom also came to endorse regime change. This undermined the logic of a sanctions regime, aimed at behavioural change induced by incentives as well as disincentives. With no end in sight to the sanctions, and constant threats to regime survival, Saddam Hussein had less reason to comply with Security Council decisions.

The 2003 decision of the United States and the United Kingdom to pursue regime change through force shattered any remaining pretence of international consensus on Iraq, leaving deep and abiding divisions among the great powers.

\section{COMING TO CONCLUSIONS FOR A CONFLICT PREVENTION STRATEGY}

Against this backdrop of Iraqi instability and international division, participants gathered in May for two days of profound and occasionally heated discussions in the relative isolation of Ottawa. The discussion began with Iraqi participants, all prominent figures that represented a cross-section of Iraq's current ethnic, religious and political divides. The Chatham House rules under which they shared their experiences prevent a thorough exposition of their views. Exposure to the dynamics of the conflict through the eyes of those that live it nevertheless left a profound impression on the conference discussions, grounding them in the reality of Iraqi experience.

Some of the Western world's foremost experts on Iraq provided a useful step backwards to sketch out the principal dimensions of the conflict. Dodge explored the security dimensions of the current conflict, making a forceful argument that state failure lies at the heart of the current insecurity and that only state-building can fully address it. Just as Max Weber defined the state as an entity with a "... legitimate monopoly on the use of physical force" throughout its territory, (Weber 1921: 396-450) Dodge argued the state must regain its monopoly before peace can return to Iraq.

Phebe Marr, perhaps the foremost US scholar of Iraq, outlined the political dimensions of the conflict. Having personally interviewed scores of the emerging leaders of each of Iraq's principal communities in 2005 , she concluded that Iraqi political leaders have to work to create a "... new vision around which most Iraqis can willingly coalesce and cooperate". Violence and conflict caused by the erosion of the state, its authority and its institutions, has led Iraqis to seek refuge in

\footnotetext{
8 These paragraphs draw again primarily on Bouillon, Malone and Rowswell 2007: 85
} 
communitarian, sectarian, tribal, and other parochial identities and interests. This process will only be reversed if Iraqi political leaders rise above the fold and begin building the foundations for a common polity responding to the basic interests of all communities.

A Sudanese-Canadian scholar, Abdel Salam Sidahmed, argued that both Islamism and Iraqi nationalism could play a positive role as tools around which an inclusive Iraqi identity could be forged. He advocated ". . . a vision of Islam devoid of sectarianism, and an Iraqi identity based on national consensus rather than a narrative of domestic oppression and external antagonism." Given the state of affairs in Iraq, this will, at best, take some time to emerge.

Jon Pederson sketched out the social and economic dimensions of the conflict, drawing from the research his Norwegian research institute, Fafo, conducted on Iraqi living conditions in 2004. ${ }^{9}$ His findings described an economy already profoundly shaped by war, and drew the sobering conclusion that "... to create a viable economy and social structure, major restructuring is needed, a restructuring that is likely to generate new conflicts."

\section{THE DOMESTIC FOUNDATIONS OF STATE-BUILDING}

Against this sobering backdrop, the discussion was joined by practitioners engaged in the daily struggle to return stability to Iraq. Nicholas Haysom, a senior UN constitutional advisor in Baghdad, drew from his experience in coping with an incipient civil war in his native South Africa, and in helping to bring the Burundian civil war to a close. While he shared the gloomy outlook of others at the conference, he nevertheless held out hope that Iraqis could pull together and forge the political consensus necessary to end the violence.

Peace must ultimately be built by the Iraqis themselves. Taking exception to one conference participant who advocated a more robust counter-insurgency operation as the path to peace, Haysom argued forcefully that peace required a new, inclusive social contract that would provide each of Iraq's major communities with a stake in the country's future. This social contract required four primary elements.

1. A substantial measure of autonomy for Kurdistan.

2. A decentralized federal arrangement for the rest of Iraq, with equitable sharing of natural resources.

3. The development of rule of law and parliamentary institutions that guarantee constitutional promises, particularly with respect to the human rights provisions contained in the constitution.

4. An appropriate framework for subordinating the military and militias to civilian control and authority, and the establishment of institutions to entrench accountability.

Achieving such an inclusive, lasting social contract will be a tall order for Iraq. It is not, however, beyond the realm of imagination. Roel Meijer, a Dutch specialist on Islamist movements who has conducted extensive research on Sunni Arab politics in Iraq, argues that even this most recalcitrant of Iraq's communities has demonstrated a willingness to engage in the kind of political discussions that might produce a social contract. His research revealed a significant shift in Sunni Arab opinion over the three years since the fall of the Ba'ath regime in favour of political participation. Of course, such participation will only find support among the wider Sunni community if the political process addresses the fear of acts of revenge for Saddam's Sunni-based regime and reverse oppression. (BBC News 2006)

\footnotetext{
9 The 2004 Iraq Living Conditions Survey was carried out by the Central Organization for Statistics and Information Technology of Iraq (COSIT) in cooperation with the Norwegian research institute Fafo. It was funded by the United Nations Development Programme (UNDP). Using a representative sample of twenty thousand households, the survey mapped a wide range of living conditions. (UNDP 2004).
} 
Persistent violence will pose the greatest challenge to achieving this political outcome. Haysom argued that an environment conducive to successful negotiations requires a ceasefire upheld by the many factions engaged in the fighting, all the way down to the level of neighbourhood militias.

Juan Cole, a leading American scholar of Iraq, was pessimistic on this front. He noted that, while ethnic and sectarian paramilitaries can "... provide local security at a time of guerrilla war and criminality on a vast scale, [they also] ... form death squads and engage in their own excesses." The reliance in particular of Shi'a political leaders on paramilitaries, as well as the strength of the Kurdish community derived from the existence and control of the peshmerga in the areas of the Kurdish Regional Government, will continue to make it difficult to confront such groups. Nevertheless, the attempt must be made.

Events may also conspire to poison efforts at national reconciliation. There will be many cases in which the commitment of Iraq's communities to find compromises and creative solutions to their diverging aspirations will be tested. One such case is that of Kirkuk, which Joost Hiltermann of the International Crisis Group addressed in detail. Kirkuk is in many ways a microcosm of the larger challenges Iraq confronts in the process of reintegrating divergent communities. Kirkuk is claimed by the Kurds, who would like to see it become the capital of their region. This assertion of Kurdish rights is contested by the city's Arabs, Turkomans, and Christians. Under the 2005 constitution, the city's status has to be determined through a census and referendum by December 2007. This will either force compromise and accommodation, or accelerate the process of a violent separation of Iraq's communities.

Sharing the revenues of Iraq's natural resources could prove another landmine for relations between Kurds and other Iraqis. In contrast to most other cases of state failure or post-conflict state-building, Iraq does have the good fortune of possessing sizeable oil reserves. This wealth has not helped so far, however, due to ongoing sectarian strife and the effects of decades-long mismanagement and politicization. The constitution adopted by Iraqis in October 2005 has reserved much, if not most, powers related to the allocation and management of natural resources for the regions and governorates, according them primacy over the federal government. The federal government is also poised to lose other powers over time, as the federalism envisaged in the constitution rolls out.

\section{ONE STATE OR MANY?}

It was in fact the Kurdish question that elicited the most heated debate at the Ottawa conference. Viciously oppressed by Saddam Hussein for much of his rule, the Kurds have had every reason to yearn for autonomy. Their provinces are the best administered in the country. Kurdish reluctance to settle for less than they have and to renounce claims to more is perfectly understandable. Many Kurds have a national project, that of creating a state of their own in northern Iraq. While this project is risky in terms of its regional implications, it is easy to understand why it commands support within the relevant area.

Indeed, some of the conference participants spoke passionately in defence of Kurdish aspirations. Others did not challenge these so much as question how compatible such aspirations are with the good will and commitment required to making Iraq's new federation work. The debate polarized discussions, revealing sharp divisions that might take hold in the international community should the Kurds pursue their national project. 
Regardless of one's views for or against, the question will not go away and threatens to generate new conflict if not managed carefully. Even if secession did not threaten to trigger a new KurdishArab front in an Iraqi civil war, it might provoke further atomization of the original state, provoking new violence as overlapping populations seek to create coherent territories where their community will rule unchallenged. The prospects for further violence are terrifying should an attempt emerge to separate out Kurdish, Shi'a and Sunni inhabitants of Baghdad and much of Iraq's central region. If the movement for a separate Kurdish state gains momentum, the more useful question for Iraq's political leaders and constitutional negotiators might be not so much whether Iraq should remain united, but what sort of relationship the various political communities of current-day Iraq should have with one another in the future.

One of the advantages of the 2005 constitution is that it provides a defensible answer to that question, one which for the time being has kept Kurdistan within Iraq. Queens University Professor John McGarry identified the basis of the constitution as democratic pluralism, or "liberal consociationalism", which he saw as a source of success since it satisfies at the very least the basic aspirations of Iraqi Kurds, while also enjoying the support of the Shi'a community. This defence of the original draft of the constitution is an important one, highlighting as it does the concerns of the Kurdish community - rightly so - and pointing to the fact that the constitution was "... endorsed by 78 out of every 100 Iraqi voters on a very high turnout."

University of Pennsylvania Law School Professor Brendan O'Leary added that, in his view, a major recalibration to accommodate Sunnis Arabs would be both unfair and unfeasible. Other participants differed, noting that because it was adopted in spite of its overwhelming rejection by Sunni Arabs, the 2005 constitution does not yet enjoy the credibility and legitimacy required if it is to serve as the bedrock of a new political order.

Like many constitutions, however, Iraq's is not set in stone. Canadian political scientist David Cameron described this constitution as a gigantic worksite. Depending how the work progresses, Cameron worried that the level of decentralization manifest in the 2005 constitution could set in motion centrifugal pressures that would break Iraq apart. To counter these, he suggested delaying the creation of regions, while giving the central government time to gather political and financial strength. Supported by a cadre of national politicians, Iraq's federal authorities could still exploit whatever areas of exclusive jurisdiction they retain, entrenching the central government's revenue-raising capacity. They could thus lay the basis for an ultimately effective and sustainable unified federal government.

\section{REGIONAL CONTRIBUTIONS TO STATE-BUILDING}

Four years after Operation Iraqi Freedom, the Middle East is a fundamentally different region than it was in 2003. The erstwhile crucible of tension, the Arab-Israeli conflict, has undergone change and has increasingly been complemented by other epicentres of instability and conflict in the broader region. The Middle East is perhaps more fragile than ever before, and Iraq provides one major source of renewed regional instability.

Should conflict there endure, Iraq's role as a magnet for radical Islamists, eager to fight US troops on Middle Eastern soil, would only increase. It could also draw neighbouring states into the quagmire as they compete for influence and using proxies to further their own interests. (Dodge 2005: 8)

In consequence, persistent failure in Iraq will have implications for governments throughout the region, regional approaches of key actors, and international involvement (or diminution thereof) 
of international players. The RAND Corporation's James Dobbins, a senior policy actor under a number of earlier US administrations, argued that the primary sources of outside support for rebuilding Iraq must henceforth come from within the region. While this is true, stating the proposition will not make it happen readily in today's circumstances. A catalytic event or process would be required to draw in the Arab League, the Organization of Islamic States and other multilateral organizations that could be helpful.

The lessons of peace-building efforts elsewhere, most notably Afghanistan and the Balkans, show that regional players are critical to the success of the international engagement. Most of Iraq's neighbours, in particular bordering Arab states, have an inherent interest in seeing the stabilization effort succeed. Others, such as Turkey and Iran need to be integrated proactively and positively into the broader international engagement, lest they jeopardize this effort. Robert Olson of the University of Kentucky noted some strong economic incentives that Turkey might have to keep Iraq stable and united. Jon Alterman of the Center for Strategic and International Studies summarized: ". .. as terrifying a prospect as Saddam Hussein was to many of them, the prospect of growing chaos in Iraq is more terrifying still." Alterman suggested that Iraq's Arab neighbours could undertake "... symbolic gestures that could help reassure those who feel left out of the current political process that they have not been abandoned".

Iran has thus far benefited most from the situation prevailing in Iraq and will be critical to efforts to bring lasting stability to the Gulf region and the new Iraqi polity. As its experience in Afghanistan since 2001 demonstrates, however, Iran may be more interested in the stability of its neighbours than in the maximization of its influence within their borders. The Islamic Republic may also have more than one view on the outcome it would prefer to Iraq's current travails. Its regional interests extend far beyond Iraq, radiating through Central Asia, the Caucasus, and, of course, the Gulf where it copes with many ancient rivalries.

\section{INTERNATIONAL SUPPORT FOR IRAQI STATE-BUILDING}

IThe main extra-regional actor in Iraq since 2003 has, of course, been the United States. Its approach to Iraq polarized the international community, with the result that the United States has had little effective support from other countries in its efforts to foster a new political order there. Coalition participation has been dropping. Spain and the Ukraine withdrew their troops in 2005; both Japan and Italy followed in 2006. John Kornblum (2006) wrote in the Washington Post:

All burdens have fallen on the Americans, but our credibility is too tarnished to handle them. Neither world public opinion nor American political dynamics will allow us to stay there long enough to stabilize Iraqi society, even if we could. No one country has either the resources or the credibility to do the job alone. We need direct and long-term engagement by other major countries, including a credible multilateral military force, and we need it fast.

If this analysis is correct, it suggests that Coalition capitals will soon be looking for ways to reengage a broad international partnership in support of Iraq in ways that bilateral imprecation has failed to achieve.

Three possible roles were discussed at the Ottawa conference that the international community could play to help stabilize Iraq: security forces to help the Iraqi state reassert its monopoly on violence; international assistance to assist with reconstruction; and political support to help Iraqis forge a common identity and an inclusive social contract. 
The prospects of new international support on the security and aid fronts both look bleak. Although Nora Bensahel of the RAND Corporation argued that the withdrawal of international troops below the minimum number necessary to fulfill the vital missions they now help carry out "... would put the future of Iraq's national government at great risk and would increase the centrifugal forces that threaten to tear the country apart", a counter-argument that Coalition forces are making the situation worse was also heard. In any event, there are unlikely to be volunteers, given the horrific level of violence there. (Malone 2006: 232-233) Pierre Gassmann, the former head of the International Committee of the Red Cross in Baghdad, argued that a new mission oriented around the responsibility to protect civilians might enjoy wider support.

Enhanced international financial assistance for Iraq is unlikely simply because the results of assistance to date are not demonstrably decisive or even good, and because of Iraq's oil wealth with so many other poorer countries in desperate need. Of course Iraq's Arab Gulf neighbours should and may help more, but they will do so only when they judge the politics of such gestures to be promising. As to the conventional Western donor group, Michael Bell pointed out that aid fatigue with respect to Iraq has already set in. To revive donor spirits would require strong leadership from the Baghdad government on reconstruction and early results.

\section{THE CONFERENCE'S CENTRAL CONCLUSION}

What remains is the prospect of increasing international engagement on political support for Iraq's fragile government and its hesitant efforts to hold the country to the rule of law, and more fundamentally, to hold it together. Only coordinated and coherent messaging from international actors inside and outside the Coalition can convince the Iraqi political class that they have no alternative but to work together to pull the country out of its downward spiral. In the absence of additional security forces or donor assistance, the most significant contribution the international community can make would be coherent and coordinated political support for domestic efforts to forge a broad and inclusive political order.

Moving from the US-led Coalition to a more broadly based international engagement would require a degree of diplomatic engineering. A credible outreach effort yielding genuine international engagement would facilitate gradual US military withdrawal, while building greater international legitimacy into the equation - for Iraq, in the region, and internationally. However, as Lakhdar Brahimi made clear in remarks, this simply will not happen as long as Washington seeks to determine what roles international actors should play and how. Active engagement on Iraq will only become attractive to nonCoalition countries and multilateral organizations if they can chart their own path freely, alongside Iraqis and the Coalition.

There is little sign yet that the United States is prepared to promote such an overtly freewheeling process. The publication in December 2006 of the Iraq Study Group, led by former secretary of state James A. Baker and former congressman Lee H. Hamilton, revealed considerable interest in US political circles beyond the Administration in drawing regional and allied partners into a more equal dialogue on Iraq's future. (Tran 2006; Sanger 2006) Nevertheless, President Bush's controversial decision the following month to surge military efforts with an additional 20,000 troops confirmed that the United States continues to prefer to set its own strategy for Iraq, even if this requires continued reliance on its own resources. 
Who would pick up the leadership role for the international community in Iraq should the United States change its current approach under a new President and agree to share real decision-making? Michael Bell and others argued that the United Nations should come to play a much more prominent role than it currently does. Given the expertise of UN staff, the ability of the United Nations to coordinate broad international reconstruction efforts, the international organization's role should be significantly strengthened, possibly by convening a multi-stakeholder Bonn-type conference (recalling Lakhdar Brahimi's success in charting a new course for Afghanistan at Bonn in late 2001).

While at the time of writing, this still seems a remote prospect; the lack of more attractive alternative approaches may lead to an early reassessment of its feasibility. Should the Coalition countries seek international assistance and partnership on open terms, the remainder of the P-5, the UN SecretaryGeneral, actors within the region would likely come forward in support. The Security Council's current posture is one of attentisme, while covering the Coalition's military presence in Iraq with a lengthy (if substantively cautious) mandate. (UN 2004) Once the Coalition is prepared to deal seriously, this could change overnight.

As Bruce Jones, a young Canadian scholar in New York and former UN political officer with excellent connections in Washington and within the UN system, noted, it is not clear that the United Nations holds out much prospect of serving as a circuit-breaker in Iraq's violence, but it has an excellent track record as an umbrella for a wide variety of diplomatic activities, not least Bonn Conference-type activities and political support operations in the field (as in Kabul, Maputo, San Salvador Freetown and Guatemala in the past).

The United Nations can also continue to provide the legal framework for the evolving international assistance to Iraq, effected under the Security Council mandate mentioned above. The United Nations' credibility within Iraq will continue to be burdened heavily for some time by the experience of the past generation of conflict and sanctions, and of collective international failure vis-a-vis Iraq and the Iraqi people. Nevertheless, in the months ahead, thought might be given to a re-structuring of the presence of international security forces on the principle of a responsibility to protect Iraqi civilians.

Jones suggested that an international contact group involving members of the Arab League and other regional players, the permanent five members of the Security Council, as well as major donors, might offer a suitable forum to underpin an enhanced international engagement. Such a contact group could be chaired, or co-chaired, by Iraqi leaders, with a secretariat supporting and coordinating international assistance specifically involving the Arab League, the World Bank, and the UN.

The full range of ideas developed at the conference can be found in Iraq: Preventing a Future Generation of Conflict. (Malone, Rowswell and Bouillon 2006)

\section{AN ASSESSMENT}

Any evaluation by the organizers of such an initiative will inevitably be self-serving to a degree. Was the initiative useful? Yes, doubtless it was in charting a path forward, identified by a process of elimination. The prospect of a short sharp departure of the Coalition from Iraq appealed to none of the participants. An alternative, thus, is required, allowing for a gradual withdrawal accompanied by a ramping up of non-Coalition involvement in support of Iraq. The formula is not original. It has been tried before, and therein lies its promise. 
Several risks to the outlook nevertheless cloud the horizon. Coalition policies are influenced by domestic politics in the United States. Will Washington be willing genuinely to share decision-making in relation to Iraq with others? It would be foolhardy to venture an affirmative response. Beyond that, and more viscerally, events on the ground daily undermine the prospect of Iraq's main communities being able to reach accommodation with each other, whatever the approach of regional and international actors. This is why the participation of supporters of greater Kurdish autonomy - even independence - was important and positive. Events on the ground, so far, are moving the reality of Iraq in the direction of their preferences, regardless of the preferences of other Iraqis and neighbouring states. Just as Slovenia, Eritrea, Montenegro took advantage of the disintegration of the states of which they had earlier formed a part, so may the Kurds ultimately reap independence from the implosion of Iraq unless the current slide towards civil war can be reversed. It is to the credit of the Kurds that they have taken no steps to aggravate the violence and discord in other areas of Iraq, including Baghdad, in order to achieve this goal some of their number have pursued for many years.

Canada's non-involvement in Coalition action against Saddam Hussein created significant challenges for Ottawa in its relationship with Washington at the time, but has since remained broadly noncontroversial within the country. Coalition members have ceased to press for greater Canadian support for their position on the ground and (at least in principle) welcome any Canadian support in developing a strategy for greater international engagement in support of the new Iraqi government. Canada's credentials include not only its non-Coalition status but also the very significant financial effort it offered in support of Iraqi reconstruction. Advice on constitutional matters from Canadian experts and Michael Bell's service as chair of the donor coordination forum all add to Canada's bona fides.

All these factors contributed to making Ottawa an excellent setting for frank talk among Iraqis from different communities and with different outlooks (enriched by the participation of other interested experts supportive of Iraqi aspirations of varying sorts) in an atmosphere of constructive, if occasionally heated, debate. The willingness of so many distinguished actors to travel to Ottawa, some at great inconvenience and some risk to themselves, spoke to both the need for greater dialogue and understanding, but also to the belief that it is possible (if challenged by violence on the ground).

This modest initiative (occasioning very modest costs) will not yield immediate dividends. It will, however, make a contribution to long-term policy development at the international level, through the development of an emerging consensus, that greater international involvement, possibly through a Bonn-type process, could help as the United Kingdom and United States seek to disengage from frontline roles in Iraq. It will have signalled that Canada remains interested in supporting a new, more hopeful, political dispensation in Iraq and Iraqi reconstruction, driven and managed by Iraqis themselves.

It will also have served to remind that when a conflict situation seems hopeless, and when the risks to enhanced engagement outweigh the benefits for Canada, targeted policy research and development can be very useful. When the short term offers no useful solutions, Canada can use policy research to shape debate about the longer term, and shape the agendas of international actors whose contributions will be necessary to longer-term solutions. 


\section{REFERENCES}

Al-Jazeera Online (2006). "Iraq Erupts into Fresh Violence." 1 March.

$<$ www.english.aljazeera.net> (September 16, 2007).

Ayubi, Nazih (1995). Over-Stating the Arab State: Politics and Society in the Middle East. London: I.B. Tauris.

Batatu, Hanna (1978). The Old Social Classes and the Revolutionary Movements of Iraq: A Study of Iraq's Old Landed and Commercial Classes and of its Communists, Ba'thists, and Free Officers. Princeton: Princeton University Press.

BBC News (2006). Iraq PM Unveils Unity Proposals, June 25.

<www.news.bbc.co.uk/1/hi/world/middle_east/5114014.stm> (September 16, 2007).

Bouillon, Markus, David M. Malone, and Ben Rowswell, eds. (2006). Iraq: Preventing A New Generation of Conflict. Boulder: Lynne Rienner.

Dodge, Toby (2005). Iraq's Future: The Aftermath of Regime Change. London: Routledge.

Dodge, Toby (2003). Inventing Iraq: The Failure of Nation-building and a History Denied. New York: Columbia University Press.

Knickmeyer Ellen and K. I. Ibrahim (2006). "Bombing Shatters Mosque In Iraq: Attack on Shiite Shrine Sets Off Protests, Violence." Washington Post, February 23: A3.

Kornblum, John (2006). "Help Wanted in Iraq." Washington Post, June 27: B1

Malone, David M. (2006). The International Struggle Over Iraq: Politics in the UN Security Council, 1980-2005. Oxford: Oxford University Press.

Migdal, Joel S. (1988). Strong Societies and Weak States: State-Society Relations and State Capabilities in the Third World. Princeton: Princeton University Press.

Owen, Roger (1992). State, Power and Politics in the Making of the Modern Middle East. London: Routledge.

Power, Samantha (2002). A Problem From Hell: America and the Age of Genocide. New York: HarperCollins.

Rotberg, Robert I. ed. (2003). Introduction. State Failure and State Weakness in a Time of Terror. Washington: Brookings Institution Press.

Rotberg, Robert I. (2002a). "The New Nature of Nation-State Failure." Washington Quarterly, (Summer) 25(3): 85-96.

Rotberg, Robert I. (2002b). "Failed States in a World of Terror." Foreign Affairs (July-August) 81(4): 127-140. 

$124 \quad \begin{aligned} & \text { Sanger, David E. (2006). "G.O.P.'s Baker Hints Iraq Plan Needs Change." New York Times, } \\ & \text { October 9: A1. }\end{aligned}$

Tran, Mark (2006). "Top US Inquiry to Call for Iraq Policy Change." The Guardian, 16 October, <www.guardian.co.uk> (September 16, 2007).

UN (2004). Resolution 1483, 22 May. New York: United Nations Security Council.

UNDP (2004). "Iraq Living Conditions Survey." Central Organization for Statistics and Information Technology of Iraq (COSIT), Norwegian research institute Fafo. New York: United Nations Development Programme. <http://www.fafo.no/ais/middeast/iraq/imira/content.htm> (August 18, 2007).

Weber, Max (1921). "Politik als Beruf. " Gesammelte Politische Schriften. Muenchen: Duncker and Humboldt.

Worth, Robert F. (2006). "Blast Destroys Shrine in Iraq, Setting Off Sectarian Fury." New York Times, February 22: A1. 